\title{
A comparison of regional monsoon variability using monsoon indices
}

\author{
So-Young Yim $\cdot$ Bin Wang $\cdot$ Jian Liu $\cdot$ \\ Zhiwei Wu
}

Received: 4 August 2013/Accepted: 23 September 2013/Published online: 5 October 2013

(C) The Author(s) 2013. This article is published with open access at Springerlink.com

\begin{abstract}
The present study aims to (a) examine meteorological basis for construction of regional monsoon indices and (b) explore the commonality and differences among tropical regional monsoons, especially the teleconnection and monsoon-ENSO relationship. We show that the area-averaged summer precipitation intensity is generally a meaningful precipitation index for tropical monsoons because it represents very well both the amplitude of annual cycle and the leading mode of year-to-year rainfall variability with a nearly uniform spatial pattern. The regional monsoon circulation indices can be defined in a unified way (measuring monsoon trough vorticity) for seven tropical monsoon regions, viz.: Indian, Australian, western North Pacific, North and South American, and Northern and Southern African monsoons. The structures of the tropical monsoons are commonly characterized by a pair of upper-level double anticyclones residing in the subtropics of both hemispheres; notably the winter hemispheric anticyclone has a barotropic structure and is a
\end{abstract}

S.-Y. Yim · B. Wang

International Pacific Research Center, University of Hawaii at Manoa, Honolulu, HI 96822, USA

B. Wang

Department of Meteorology, University of Hawaii at Manoa, Honolulu, HI 96822, USA

J. Liu ( $\square)$

Key Laboratory of Virtual Geographic Environment of Ministry of Education, School of Geography Science, Nanjing Normal University, Nanjing 210023, China

e-mail: jliu@njnu.edu.cn

\section{Z. Wu}

School of Atmospheric Sciences, Nanjing University of Information Science and Technology, Nanjing 210044, China passive response. Two types of upper-level teleconnection patterns are identified. One is a zonal wave train emanating from the double anticyclones downstream along the westerly jets in both hemispheres, including Indian, Northern African and Australian monsoons; the other is a meridional wave train emanating from the double anticyclones polewards, such as the South American and western North Pacific monsoons. Over the past 55 years all regional summer monsoons have non-stationary relationship with ENSO except the Australian monsoon. The regional monsoon-ENSO relationship is found to have common changing points in 1970s. The relationships were enhanced for the western North Pacific, Northern African, North American and South American summer monsoons, but weakened for the Indian summer monsoon (with a recovery in late 1990s). Regardless the large regional differences, the monsoon precipitations over land areas of all tropical monsoon regions are significantly correlated with the ENSO, suggesting that ENSO drives global tropical monsoon rainfall variability. These results provide useful guidance for monitoring sub-seasonal to seasonal variations of the regional monsoons currently done at NCEP and for assessment of the climate models' performances in representing regional and global monsoon variability.

Keywords Regional monsoon - Precipitation index · Circulation index · ENSO-monsoon relationship .

Teleconnection $\cdot$ Interdecadal change

\section{Introduction}

The global monsoon is a response of the coupled atmosphere-land-ocean system to the annual variation in solar radiation and is characterized by a global-scale seasonal 
reversal of prevailing surface winds and the associated seasonal contrast in precipitation (Wang et al. 2012a). The global monsoon precipitation domain consists of eight regional monsoons: Indian (IN), western North Pacific (WNP), East Asian (EA), Australian (AUS), North American (NAM), South American (SAM), Northern African (NAF), and Southern African (SAF) (Fig. 1). These regions are characterized by a sharp contrast between rainy summer and dry winter. Among the eight regional monsoons, EA monsoon is a subtropical monsoon, the others are tropical monsoons.

Although the regional monsoon variations can be well coordinated under external forcing on orbital time scale (Liu et al. 2004) and on centennial-submillennial time scales (Liu et al. 2009), they tend to be less well coordinated on shorter (interannual to interdecadal) time scales and exhibit more regional differences, because on these shorter time scales internal feedback processes are major drivers (Wang et al. 2012a, 2013). In addition, the regional monsoons have their own characteristic structures owing to specific land-ocean and topographic configuration (McBride 1987; Tao and Chen 1987; Nicholson and Kim 1997; Webster et al. 1998; Zhou and Lau 1998; Higgins et al. 2003).

To facilitate monitoring, prediction and study of the variability and predictability of regional monsoons, various precipitation and circulation indices have been conveniently used to depict overall variations of each regional monsoon. All Indian precipitation index (Parthasarathy et al. 1992) is such an example. Besides precipitation indices, circulation variables were also used to quantify the strength of the monsoon circulation system. For instance, Webster and Yang (1992) proposed an Asian monsoon

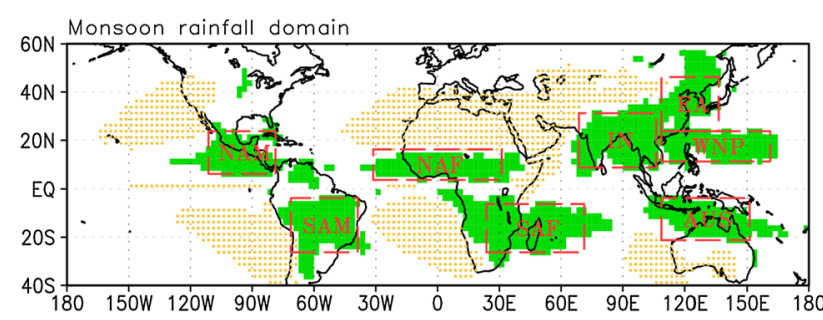

Fig. 1 Regional monsoon precipitation domains (shaded, green) defined by the regions in which a the annual range (AR) of precipitation rates exceeds $2 \mathrm{~mm} /$ day (or $300 \mathrm{~mm}$ per season) and b the local summer precipitation exceeds $55 \%$ of the total annual rainfall. Here the AR is defined as May through September (MJJAS) precipitation minus November through March (NDJFM) precipitation in the NH and NDJFM minus MJJAS precipitation in the SH. Also shown are the approximate rectangular domains of regional monsoons and their names. The threshold values used here distinguish the monsoon climate from the adjacent dry regions where the local summer precipitation less than $1 \mathrm{~mm} /$ day (stippled, yellow). The merged CMAP-GPCP data were used. Adopted from Wang et al. (2012a) vertical shear index to measure the interannual variability of the entire Asian summer monsoon circulation system. Subsequently, the Indian monsoon circulation indices and western North Pacific-East Asian monsoon circulation indices (Wang and Fan 1999; Goswami et al. 1999; Wang et al. 2001), as well as Australian monsoon indices (Kajikawa et al. 2009) were proposed and frequently used for studying interannual and decadal variability.

The existing regional monsoon indices have been constructed in some of the eight monsoon regions using variety of variables and various ways but without unified methods. Is it possible to define unified regional monsoon indices? What is the meteorological basis for constructing such indices? Our first objective in the present study is to address this unanswered question by analysis of the spatial-temporal structure of the leading mode of variability at each monsoon region. Based on the understanding gained from this analysis we propose a unified approach to define circulation indices for all regional components, including those regions that have no available indices. These indices will facilitate mining the physical drivers behind the monsoon variability and establishing its linkages to climate variations in remote regions of the climate system and its hydrological, ecological and socioeconomic impacts.

Since previous monsoon studies mostly focus on each individual region, our second objective is to find the commonality and differences among tropical regional monsoons by comparing the teleconnection patterns associated with each regional monsoon and regional monsoonEl Niño-Southern Oscillation (ENSO) relationship on interannual and interdecadal time scale. This analysis is expected to add new knowledge to monsoon variability on global scale and to stimulate further theoretical and numerical studies to better understand monsoon dynamics.

The datasets and methodology used are given in Sect. 2. We introduce the meteorological reasons for establishing regional monsoon precipitation indices in Sect. 3 and propose a unified way to define regional monsoon circulation indices in Sect. 4. The teleconnections associated with each regional monsoon precipitation, as well as the regional monsoon-ENSO relationships are discussed in Sects. 5 and 6, respectively. Section 7 presents conclusion and discussion.

\section{Data and methodology}

There are two global (land and ocean) precipitation datasets available: Global Precipitation Climatology Project (GPCP, Huffman et al. 2011) and Climate prediction center Merged Analysis of Precipitation (CMAP, Xie and Arkin 1997). We used the GPCP data except for description of monsoon domain which was obtained from an arithmetic 
Table 1 The correlation coefficients between the regional monsoon precipitation intensities in the rectangular domains and other precipitation intensity parameters: (a) local summer-mean (JJAS in NH or
DJFM in SH) rainfall rate, (b) annual range (AR, JJAS minus DJFM in $\mathrm{NH}$ and DJFM minus JJAS in SH) of rainfall rate, and (c) annual mean rainfall rate

\begin{tabular}{lllll}
\hline $\begin{array}{l}\text { Regional } \\
\text { monsoon }\end{array}$ & $\begin{array}{l}\text { Rectangular } \\
\text { monsoon domain }\end{array}$ & $\begin{array}{l}\text { Summer monsoon } \\
\text { precipitation intensity } \\
\text { in the realistic monsoon } \\
\text { region }\end{array}$ & $\begin{array}{l}\text { Annual range of the precipitation } \\
\text { rate in the rectangular } \\
\text { monsoon region }\end{array}$ & $\begin{array}{l}\text { Annual mean precipitation } \\
\text { rate in the rectangular } \\
\text { monsoon region }\end{array}$ \\
\hline IN & $10^{\circ} \mathrm{N}-30^{\circ} \mathrm{N}, 70^{\circ} \mathrm{E}-105^{\circ} \mathrm{E}$ & $\mathbf{0 . 9 9}$ & $\mathbf{0 . 8 9}$ & $\mathbf{0 . 7 3}$ \\
WNP & $12.5^{\circ} \mathrm{N}-22.5^{\circ} \mathrm{N}, 110^{\circ} \mathrm{E}-150^{\circ} \mathrm{E}$ & $\mathbf{0 . 9 9}$ & $\mathbf{0 . 9 1}$ & $\mathbf{0 . 5 9}$ \\
EA & $22.5^{\circ} \mathrm{N}-45^{\circ} \mathrm{N}, 110^{\circ} \mathrm{E}-135^{\circ} \mathrm{E}$ & $\mathbf{0 . 6 8}$ & $\mathbf{0 . 8 4}$ & $\mathbf{0 . 5 2}$ \\
NAM & $7^{\circ} \mathrm{N}-22.5^{\circ} \mathrm{N}, 110^{\circ} \mathrm{W}-80^{\circ} \mathrm{W}$ & $\mathbf{0 . 9 6}$ & $\mathbf{0 . 9 5}$ & $\mathbf{0 . 7 4}$ \\
NAF & $5^{\circ} \mathrm{N}-15^{\circ} \mathrm{N}, 30^{\circ} \mathrm{W}-30^{\circ} \mathrm{E}$ & $\mathbf{0 . 9 8}$ & $\mathbf{0 . 8 8}$ & $\mathbf{0 . 9 5}$ \\
SAM & $5^{\circ} \mathrm{S}-25^{\circ} \mathrm{S}, 70^{\circ} \mathrm{W}-40^{\circ} \mathrm{W}$ & $\mathbf{0 . 9 8}$ & $\mathbf{0 . 9 5}$ & $\mathbf{0 . 7 3}$ \\
SAF & $7^{\circ} 5^{\circ} \mathrm{S}-25^{\circ} \mathrm{S}, 25^{\circ} \mathrm{E}-70^{\circ} \mathrm{E}$ & $\mathbf{0 . 9 5}$ & $\mathbf{0 . 8 9}$ & $\mathbf{0 . 8 6}$ \\
AUS & $5^{\circ} \mathrm{S}-20^{\circ} \mathrm{S}, 110^{\circ} \mathrm{E}-150^{\circ} \mathrm{E}$ & $\mathbf{0 . 9 8}$ & $\mathbf{0 . 8 9}$ \\
\hline
\end{tabular}

The GPCP V2 data were used for the period 1979-2012. The bolded numbers represent significant at $99 \%$ confidence level

mean of the two datasets for the period 1979-2012. The gridded monthly precipitation data CRU TS 3.1 (Climatic Research Unit, University of East Anglia) with spatial resolution $0.5 \times 0.5$ covering all land areas (Mitchell and Jones 2005) are used for a longer period 1958-2009.

The circulation and sea surface temperature (SST) data used are derived from ERA interim (Dee et al. 2011) and the National Oceanic and Atmospheric Administration extended reconstructed SST version 3 (Smith et al. 2008), respectively. To derive anomalous monsoon structures and circulation indices for each regional monsoon, we perform the correlation analysis using zonal and meridional winds at $850 \mathrm{hPa}$ (UV850), sea level pressure (SLP), zonal and meridional winds at $200 \mathrm{hPa}$ (UV200), and geopotential height at $200 \mathrm{hPa}(\mathrm{H} 200)$ that are associated with time series of regional monsoon precipitation indices. Monthly mean anomalies from June to September for $\mathrm{NH}$ and from December to March for SH are used to reflect sub-seasonal and interannual variations for the period 1979-2012 during which reliable global precipitation observation are available. For a longer regional monsoon circulation index, the period used is extended from 1958 to 2012 using a combination of the 40-year reanalysis (ERA-40) data (Uppala et al. 2005) and ERA interim.

\section{Meteorological basis for constructing regional monsoon precipitation indices}

Figure 1 presents the global monsoon domain defined by using merged CMAP-GPCP rainfall climatology. Although each of the eight regional monsoon domains is irregular, they can be approximately represented by the corresponding rectangular boxes as shown in Fig. 1 and defined in Table 1. Use of the simplified rectangular domain will facilitate computation of the regional summer monsoon precipitation intensity. As shown in Table 1, the total rainfall amounts averaged over the corresponding rectangular regions represent extremely well the corresponding counterparts averaged over the real regional monsoon domain: their correlation coefficients $(\mathrm{CCs})$ range from 0.95 to 0.99 except the EA subtropical monsoon (0.68). Thus, we shall use the approximate rectangular regions to represent the respective tropical regional monsoon domains.

Figure 2 shows the seasonal distribution of precipitation for each of eight approximate rectangular domains, i.e., IN, WNP, EA, NAM, NAF, SAM, SAF, and AUS. The IN, NAM, and NAF have peaks in JJAS (June to September), while the WNP and EA have different peaks occurring in JASO (July to October) and MJJA (May to August), respectively. On the other hand, all the SH summer monsoon components, that is, SAM, SAF, and AUS have peaks in DJFM (December to following March). Therefore, the JJAS and DJFM could be considered as local summer monsoon seasons in $\mathrm{NH}$ and $\mathrm{SH}$, respectively.

The monsoon precipitation indices are normally defined as the area-averaged local summer precipitation rate or total amount of rainfall. What is the physical basis for using area-averaged summer rainfall intensity as a measure of regional monsoon intensity? In the next two paragraphs we shall examine (a) whether a local summer rainfall intensity can represent the annual range (contrast of wet summer and dry winter) well to provide a good measure of the strength of the regional monsoon annual cycle; and (b) whether an area-averaged index can represent the leading mode of rainfall variability well to provide a convenient measure of the regional monsoon variability.

Table 1 compares three intensity parameters averaged over each regional monsoon region represented by the 
Fig. 2 Climatological annual cycle of precipitation rates in the eight regional monsoon domains. The GPCP V2 data were used. The horizontal dashed line indicates the climatological mean value in each regional summer monsoon rainfall (a) $\mathrm{IN}$

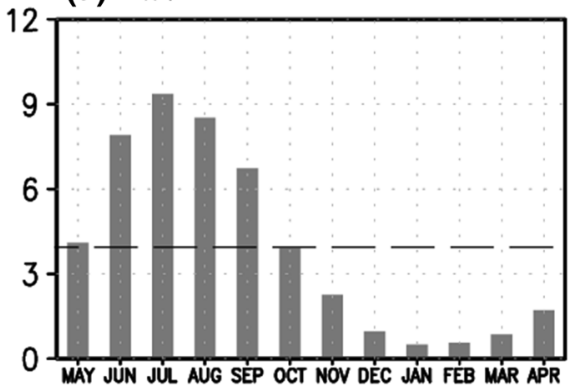

(b) WNP

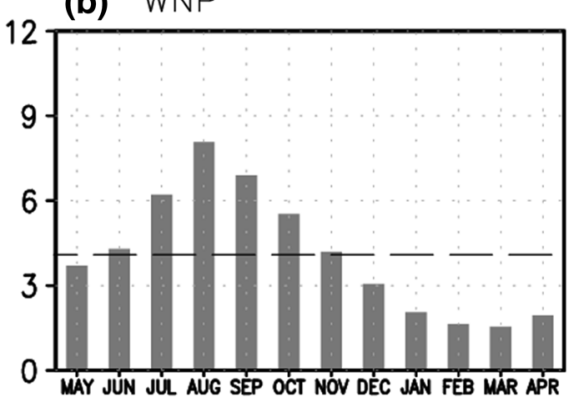

(c) EA

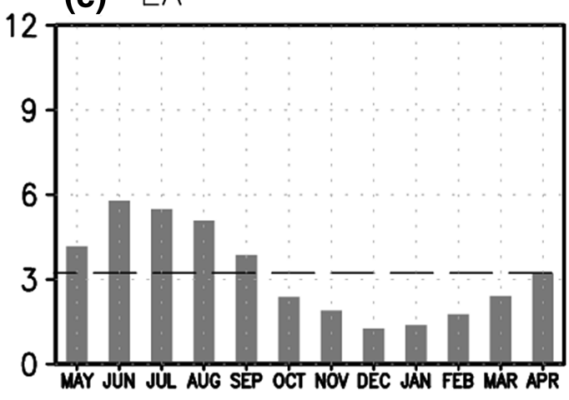

(d) NAM

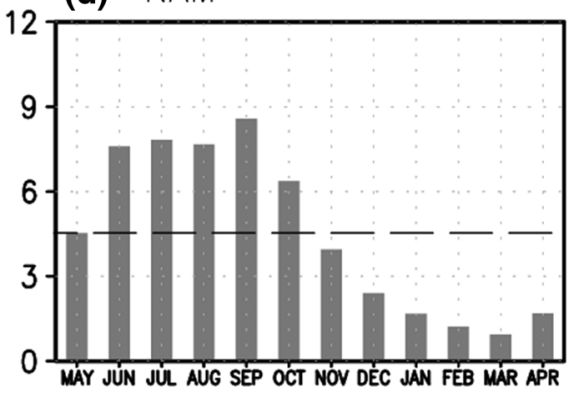

(e) NAF

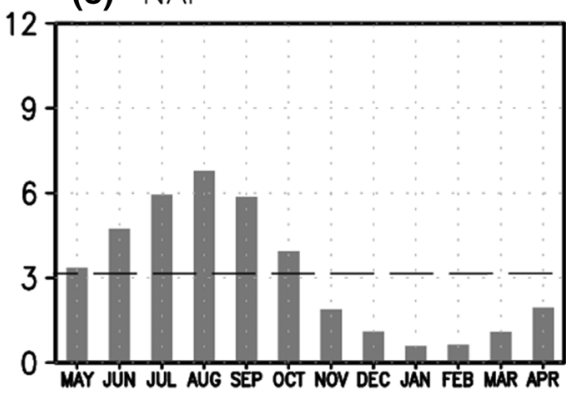

(f) SAM

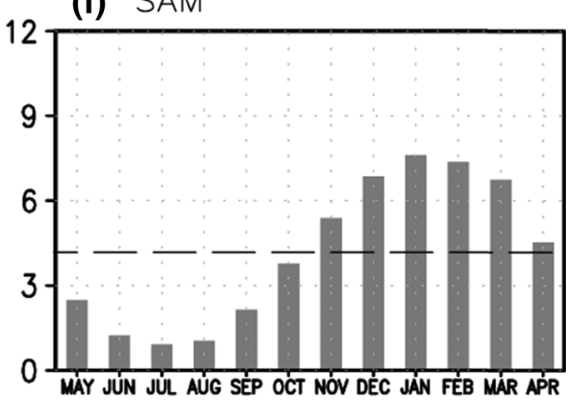

(g) SAF

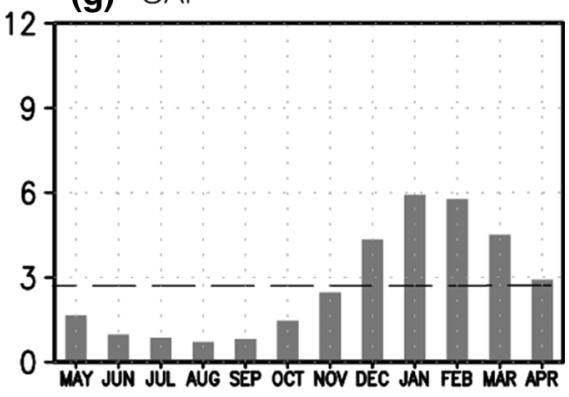

(h) $A \cup S$

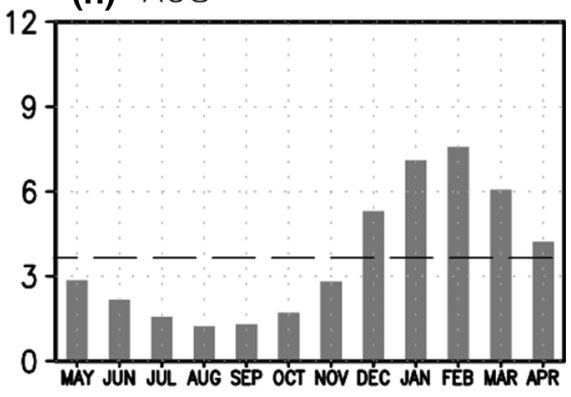

corresponding rectangular domains: (a) local summer (JJAS or DJFM) mean rainfall rates, (b) annual range (AR, JJAS minus DJFM in NH and DJFM minus JJAS in SH) of rainfall, and (c) annual mean rainfall rates. The local summer monsoon precipitation intensity is highly correlated with the annual range (CCs vary from 0.84 to 0.95 ), indicating that local summer monsoon precipitation rate represents the amplitude of the regional monsoon annual cycle very well. Further, to a large extent, the local summer monsoon rainfall intensity also reflects the annual total precipitation strength in most regional monsoons (CCs vary from 0.73 to 0.95 ) except the WNP and EA monsoons. The WNP and EA monsoons have different rainfall peaks in JASO and MJJA, respectively, and their contrasts of wet summer and dry winter are less than those of other regional monsoons.

The principal component (PC) of the leading mode of regional monsoon variability has been used as the meteorological basis to measure the monsoon strength variations in East Asia (e.g., Wang et al. 2008a). Here we examined 
Fig. 3 The leading EOF modes of local summer mean precipitation (JJAS in $\mathrm{NH}$ and DJFM in SH) over each of eight monsoon domains. The monthly mean precipitation anomalies were used. The number in the lower-left corner indicates the temporal correlation coefficient between area-averaged regional monsoon precipitation index and the leading principal component. The percentage in the title of each panel indicates the explained variance (a) $\operatorname{ISM}(17.2 \%)$

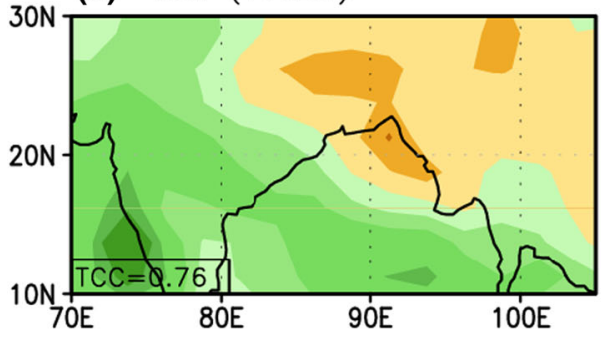

(b) WNPSM (26.9\%)

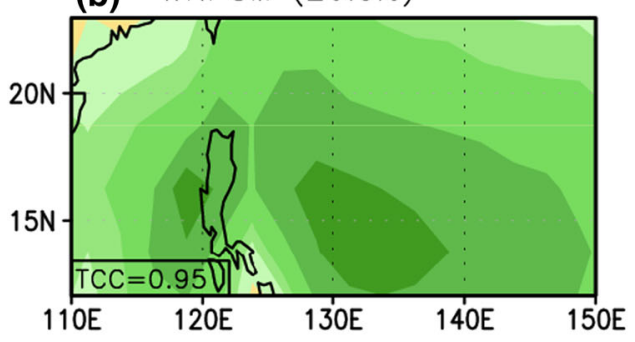

(c) $\operatorname{EASM}(16.0 \%)$

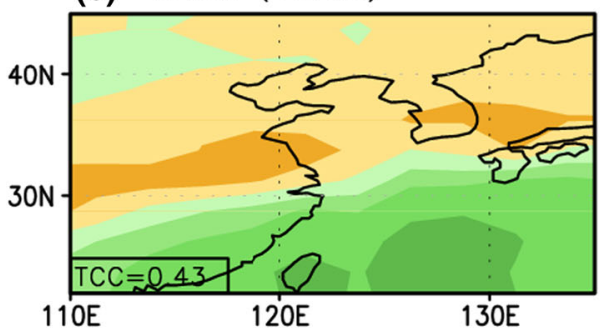

(d) NASM (29.2\%)

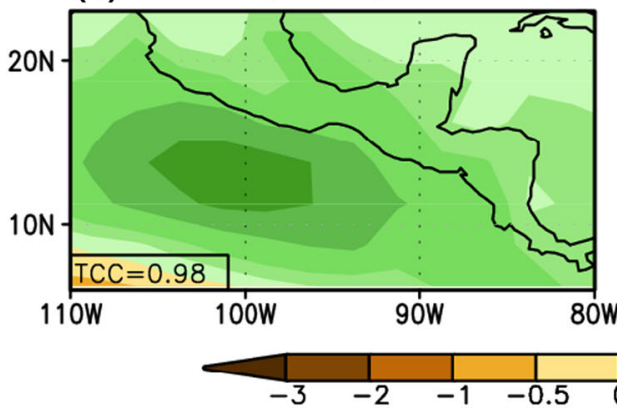

(e) NAFSM (17.9\%)

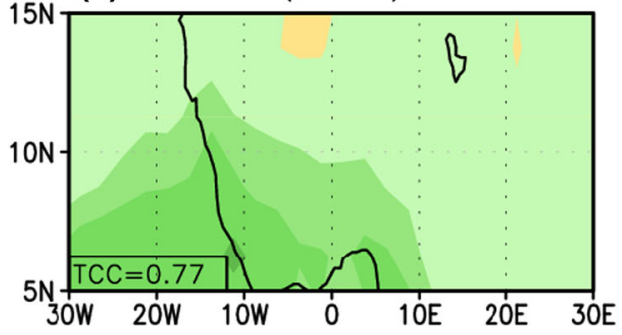

(f) $\operatorname{SASM}(29.8 \%)$

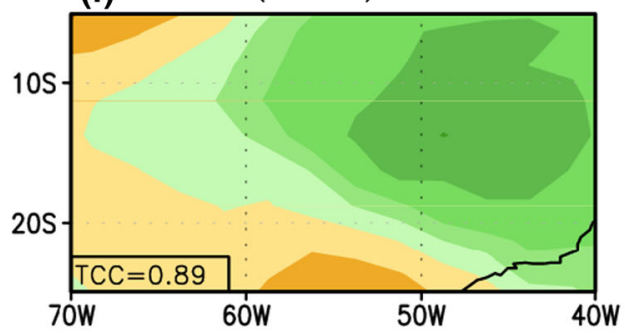

(g) SAFSM (17.5\%)

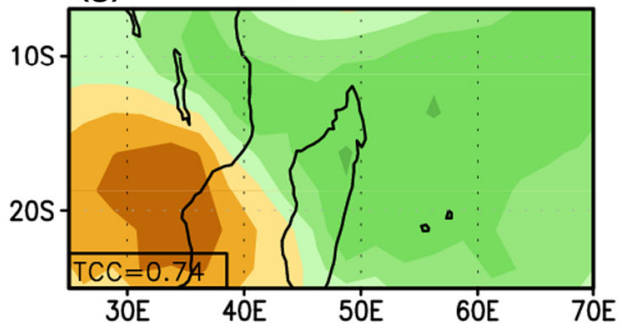

(h) $\operatorname{AUSSM}(26.7 \%)$

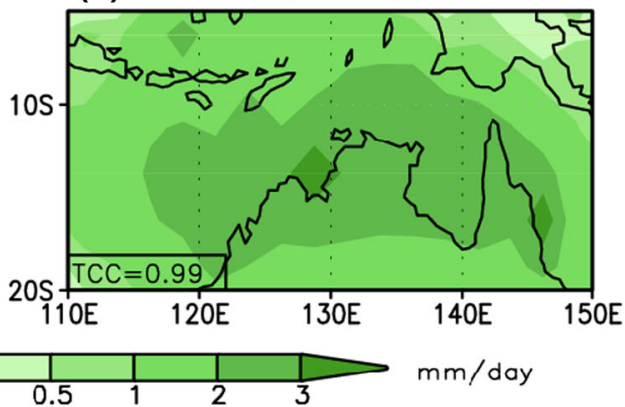

whether an area-averaged precipitation index is appropriate for depicting the regional monsoon variability through the empirical orthogonal function (EOF) analysis. Figure 3 shows that all the regional monsoon precipitation indices correlate well or very well with the corresponding leading PCs (The CCs range from 0.74 to 0.99 ) except EA subtropical monsoon (0.43). The WNP, NAM and AUS summer monsoon precipitation indices are nearly identical to the corresponding leading PCs, and the corresponding spatial patterns are also nearly uniform. Thus, the areaaveraged monsoon precipitation indices in our study are generally suitable to depict the variability of the tropical regional monsoons. The East Asian summer monsoon (EASM) is different from the seven tropical monsoons. Its leading mode is dominated by a north-south dipole pattern and not well correlated with PC1 temporally. Because of the specific features of the subtropical EASM, hereafter we will exclude it and focus on the common and different features of the seven tropical regional monsoons.

In summary, we found that area-averaged summer precipitation indices represents well (a) the amplitude of annual cycle (monsoon strength), (b) the principal components of the summer-to-summer rainfall variability, and (c) the corresponding spatial patterns are nearly uniform in most tropical monsoon regions, thereby providing a meaningful measure of the regional monsoon rainfall intensity. However, we found that EASM is an exception where an area averaged index does not represents the PC of leading EOF. Cautions should also be exercised for Indian and Southern African summer monsoons because although 

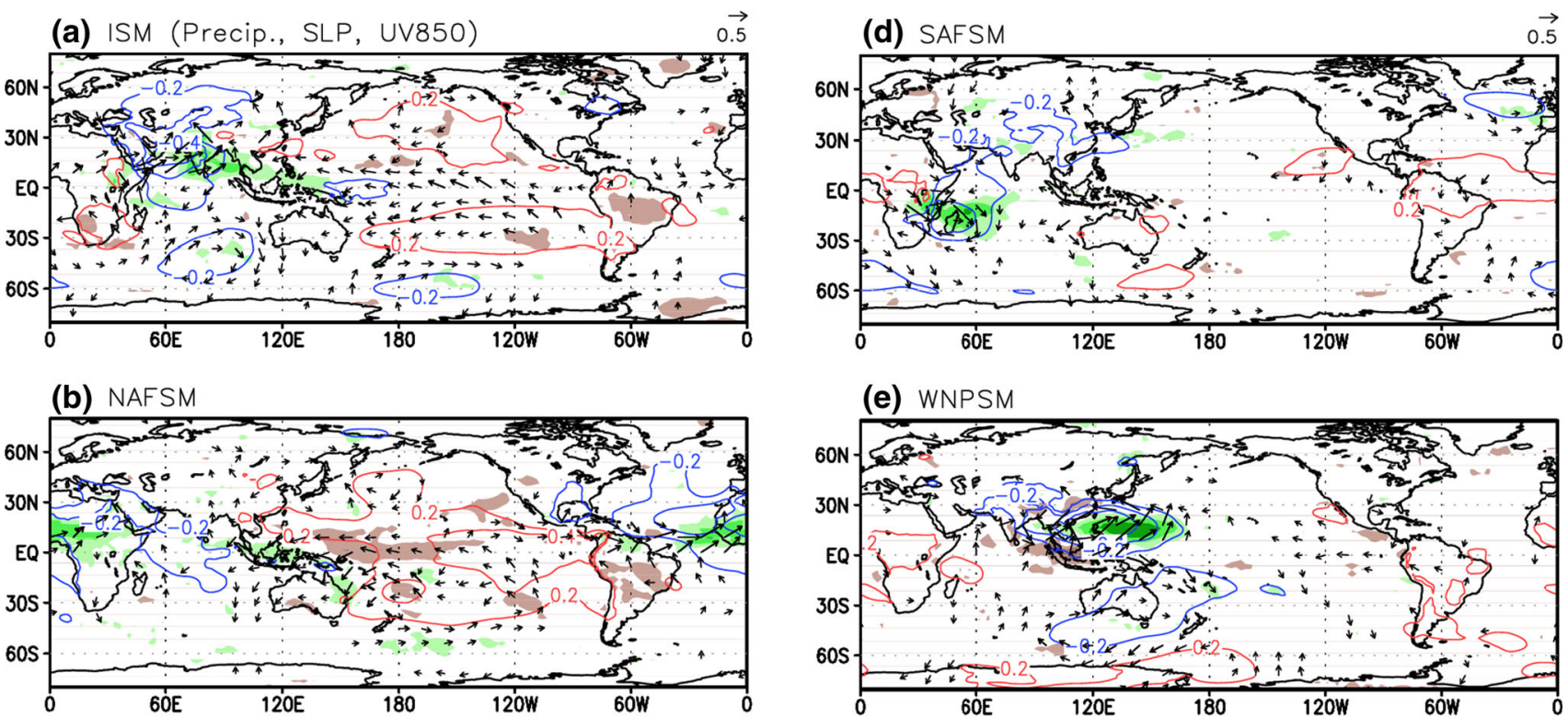

(e) WNPSM

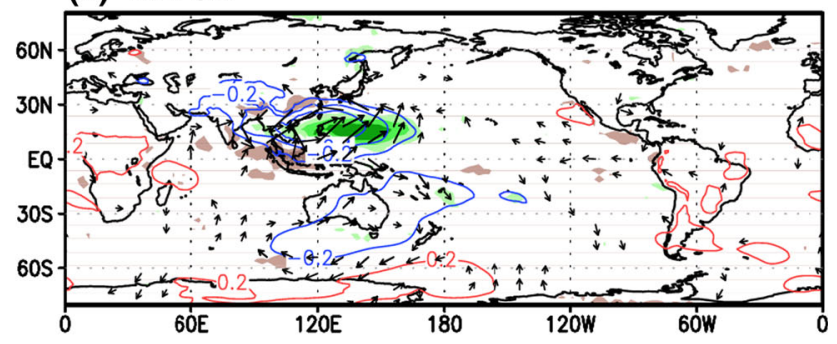

(c) AUSSM

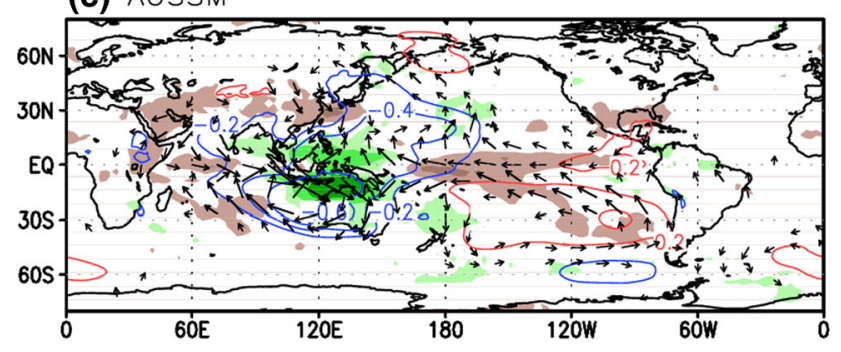

(f) SASM

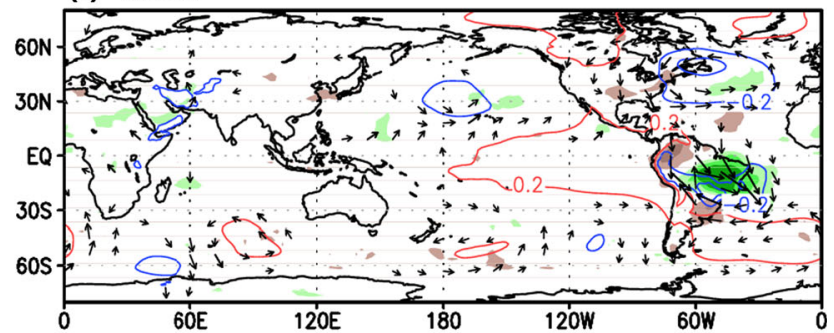

(g) NASM

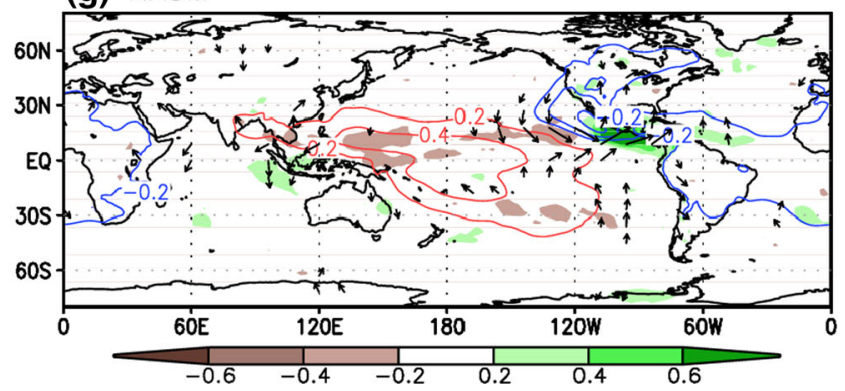

Fig. 4 Simultaneous correlation coefficient map of precipitation (shading), SLP (contour), $850 \mathrm{hPa}$ winds (vectors) with respect to the time series of each regional summer monsoon precipitation index. The solid red and blue contours represent positive and negative SLP

the PCs are related to rainfall indices, the spatial patterns of the leading modes are not uniform and their fractional variances are relatively low.

\section{Construction of monsoon circulation indices in a unified approach}

In this section, we shall first derive common features of the rainfall-circulation structure, and then propose regional anomalies, respectively. The vector correlation was calculated using the best scalar correlation for either zonal or meridional wind component

monsoon indices in a unified approach, which will provide new indices for those regions that have no indices. We also compare the unified indices with the corresponding existing indices to see whether there is an improvement.

\subsection{Anomalous monsoon structures in each of seven tropical regional monsoons}

Figure 4 shows correlation maps of precipitation, SLP and $850 \mathrm{hPa}$ winds with reference to each tropical regional 
monsoon precipitation index. These figures are used to describe the low-level anomalous monsoon structures in this subsection and to define the circulation indices in the next subsection.

1. Indian summer monsoon (ISM) has elongated positive rainfall anomalies along the monsoon trough extending from the eastern Arabian Sea to Bay of Bengal. Enhanced ISM rainfall is associated with a strong cyclonic circulation anomaly with westerlies between $5^{\circ} \mathrm{N}$ and $15^{\circ} \mathrm{N}$ and easterlies over northern India (Fig. 4a).

2. Northern African summer monsoon (NAFSM): Most studies of African monsoon focus on West African monsoon only. The NAFSM defined in this study covers West Africa and eastern North Africa $\left(5^{\circ} \mathrm{N}-\right.$ $15^{\circ} \mathrm{N}, \quad 30^{\circ} \mathrm{W}-30^{\circ} \mathrm{E}$ ) (Fig. $4 \mathrm{~b}$ ). The westerly wind anomalies prevail along the tropical Atlantic, which brings the moisture to the NAF region. Northward cross-equatorial flows are seen over the Atlantic Ocean associated with the enhanced NAFSM.

3. Australian summer monsoon (AUSSM): The circulation anomalies associated with a strong AUSSM rainfall are characterized by very strong westerly wind anomalies over the region $0^{\circ} \mathrm{S}-15^{\circ} \mathrm{S}, 90^{\circ} \mathrm{E}-130^{\circ} \mathrm{E}$ and easterly wind anomalies over the region $20^{\circ} \mathrm{S}-30^{\circ} \mathrm{S}$, $100^{\circ} \mathrm{E}-140^{\circ} \mathrm{E}$ resulting in enhanced cyclonic circulation and low pressure anomalies over southeast tropical Indian Ocean and northwestern Australia (Fig. 4c).

4. Southern African summer monsoon (SAFSM): The enhanced SAFSM rainfall anomalies are located northern Madagascar including part of Southwestern Indian Ocean convergence zone and TanzaniaMozambique. The associated low-level cyclonic anomaly is centered at Madagascar (Fig. 4d).

5. Western North Pacific summer monsoon (WNPSM): during a strong WNPSM, rainfall increases significantly in a zonally oriented band along $10^{\circ} \mathrm{N}-20^{\circ} \mathrm{N}$ over WNP region and associated anomalous cyclonic anomalies with westerly anomalies between $5^{\circ} \mathrm{N}$ and $15^{\circ} \mathrm{N}$ and easterly anomalies between $20^{\circ} \mathrm{N}$ and $35^{\circ} \mathrm{N}$ are seen in the $850 \mathrm{hPa}$ wind field (Fig. 4e).

6. South American summer monsoon (SASM): The enhanced SASM rainfall covers most regions of the Brazil and the enhanced low-level cyclonic anomalies occupy most of tropical and subtropical South American continent (Fig. 4f). During a strong SASM, westerly anomalies are observed over the core of the Amazon basin extending toward southeast Brazil, forming the cyclonic circulation over the subtropics of South America.
Table 2 Definition of the vorticity circulation indices for each tropical regional summer monsoon and their correlation coefficients (CCs) with the corresponding tropical regional summer monsoon precipitation indices

\begin{tabular}{lll}
\hline & Definition of vorticity circulation index & CC \\
\hline ISM & U850 $\left(5^{\circ} \mathrm{N}-15^{\circ} \mathrm{N}, 40^{\circ} \mathrm{E}-80^{\circ} \mathrm{E}\right)-$ & $\mathbf{0 . 7 6}$ \\
& $\mathrm{U} 850\left(25^{\circ} \mathrm{N}-35^{\circ} \mathrm{N}, 70^{\circ} \mathrm{E}-90^{\circ} \mathrm{E}\right)$ & \\
WNPSM & $\mathrm{U} 850\left(5^{\circ} \mathrm{N}-15^{\circ} \mathrm{N}, 100^{\circ} \mathrm{E}-130^{\circ} \mathrm{E}\right)-$ & $\mathbf{0 . 8 1}$ \\
& $\mathrm{U} 850\left(20^{\circ} \mathrm{N}-35^{\circ} \mathrm{N}, 110^{\circ} \mathrm{E}-140^{\circ} \mathrm{E}\right)$ & \\
NASM & $\mathrm{U} 850\left(5^{\circ} \mathrm{N}-15^{\circ} \mathrm{N}, 130^{\circ} \mathrm{W}-100^{\circ} \mathrm{W}\right)-$ & $\mathbf{0 . 8 2}$ \\
& $\mathrm{U} 850\left(20^{\circ} \mathrm{N}-30^{\circ} \mathrm{N}, 110^{\circ} \mathrm{W}-80^{\circ} \mathrm{W}\right)$ & \\
NAFSM & $\mathrm{U} 850\left(0^{\circ} \mathrm{N}-15^{\circ} \mathrm{N}, 60^{\circ} \mathrm{W}-10^{\circ} \mathrm{W}\right)$ & $\mathbf{0 . 7 5}$ \\
SASM & $\mathrm{U} 850\left(5^{\circ} \mathrm{S}-20^{\circ} \mathrm{S}, 70^{\circ} \mathrm{W}-40^{\circ} \mathrm{W}\right)-$ & $\mathbf{0 . 8 1}$ \\
& $\mathrm{U} 850\left(20^{\circ} \mathrm{S}-35^{\circ} \mathrm{S}, 70^{\circ} \mathrm{W}-40^{\circ} \mathrm{W}\right)$ & $\mathbf{0 . 7 1}$ \\
SAFSM & $\mathrm{U} 850\left(5^{\circ} \mathrm{S}-15^{\circ} \mathrm{S}, 20^{\circ} \mathrm{E}-50^{\circ} \mathrm{E}\right)-$ & \\
& $\mathrm{U} 850\left(20^{\circ} \mathrm{S}-30^{\circ} \mathrm{S}, 30^{\circ} \mathrm{E}-55^{\circ} \mathrm{E}\right)$ & $\mathbf{0 . 9 0}$ \\
AUSSM & $\mathrm{U} 850\left(0^{\circ} \mathrm{S}-15^{\circ} \mathrm{S}, 90^{\circ} \mathrm{E}-130^{\circ} \mathrm{E}\right)-$ & \\
& $\mathrm{U} 850\left(20^{\circ} \mathrm{S}-30^{\circ} \mathrm{S}, 100^{\circ} \mathrm{E}-140^{\circ} \mathrm{E}\right)$ & \\
\hline
\end{tabular}

The correlation coefficients were applied using monthly data (JuneSeptember in NH and December-March in SH). The bolded numbers represent significance at $99 \%$ confidence level

7. North American summer monsoon (NASM) is characterized by a local cyclonic anomaly with distinct rainfall maxima over western Mexico and the southwestern United States, which is associated with anomalous westerlies to the southwest of the anomalous cyclone transporting water vapor from the eastern tropical Pacific and the Gulf of California (Fig. 4g). Cross-equatorial flows from $\mathrm{SH}$ to $\mathrm{NH}$ are seen over the far eastern equatorial Pacific.

\subsection{Construction of monsoon circulation indices using low-level vorticity}

The enhanced regional monsoon precipitation is commonly characterized by a low-level cyclonic circulation at the west of the anomalous precipitation and strong westerly anomalies in the westward and equatorward side of the enhanced monsoon precipitation. Based on the anomalous monsoon structures (Fig. 4), the regional monsoon circulation intensity indices over most monsoon regions can be defined using the difference of the $850 \mathrm{hPa}$ zonal winds between a southern region and a northern region near the core area of each monsoon precipitation center, which describe the low-level vorticity of the monsoon trough (Table 2). Exception is Northern African monsoon regions and the $850 \mathrm{hPa}$ zonal winds were used for the NAFSM circulation index.

Each regional monsoon precipitation index is well correlated with the corresponding regional monsoon 
circulation index as shown in Table 2; the CCs range from 0.71 to 0.90 , suggesting that the circulation indices reflect regional monsoon rainfall variability reasonably well. Because of the circulation data are more reliable and have longer records than precipitation data, these circulation indices are suitable for study of interdecadal variations. The circulation indices defined for the WNPSM and AUSSM are slightly different from the existing circulation indices. Thus a brief comparison seems necessary. Wang et al. (2001) defined WNPSM index as U850 $\left(5^{\circ} \mathrm{N}-15^{\circ} \mathrm{N}\right.$, $\left.100^{\circ} \mathrm{E}-130^{\circ} \mathrm{E}\right)$ minus $\mathrm{U} 850\left(20^{\circ} \mathrm{N}-30^{\circ} \mathrm{N}, 110^{\circ} \mathrm{E}-140^{\circ} \mathrm{E}\right)$, which is almost the same as the one defined in our study except for a bit narrower northern region $\left(20^{\circ} \mathrm{N}-30^{\circ} \mathrm{N}\right.$ vs. $\left.20^{\circ} \mathrm{N}-35^{\circ} \mathrm{N}\right)$. The correlation coefficient with precipitation index is 0.73 for Wang et al. (2001) and 0.81 in this study for the 136 summer months of 1979-2012. Kajikawa et al. (2009) defined AUSMI by low-level westerlies, U850 $\left(5^{\circ} \mathrm{S}-15^{\circ} \mathrm{S}, 110^{\circ} \mathrm{E}-130^{\circ} \mathrm{E}\right)$, rather than horizontal wind shear (vorticity). The correlation coefficient with the precipitation index is 0.85 for Kajikawa et al. (2009) and 0.90 for the present index.

\section{Teleconnection patterns associated with each of regional monsoons}

Regional monsoon fluctuations can have important impacts on remote regions through teleconnection. Previous studies have found teleconnection patterns associated with various regional monsoons, such as ISM (Wang et al. 2001; Ding and Wang 2005; Lin 2009; Ding et al. 2011), WNPSM (Wang et al. 2001; Lin 2009), NASM (Moon et al. 2012), and NAFSM (Wang et al. 2012b). Here we provide a summary on known regional monsoon teleconnection features and implemented unknown features. Figure 5 shows correlation maps of precipitation, $200 \mathrm{hPa}$ geopotential height (H200), and $200 \mathrm{hPa}$ wind (UV200) anomalies with reference to each regional monsoon precipitation index. These figures are used to describe monsoon teleconnection patterns.

The enhanced ISM rainfall anomalies generates an upper-level anomalous high to its northwest over westcentral Asia and then excites a zonally oriented wave train along the westerly jet-related waveguide (Fig. 5a). This confirms the circumglobal teleconnection pattern identified in Wang et al. (2001) and Ding and Wang (2005). It is notable that a strong ISM also generates very strong cross equatorial flows southward and excites a strong Mascarene High, which further induces an associated SH mid-latitude wave train.

The enhanced NAFSM rainfall tends to generate southward cross equatorial flows and excites an upper-level anticyclone over South Africa (Fig. 5b). These double anticyclones in the upper troposphere, similar to those of the ISM, induce downstream wave train along the westerly jet though Rossby wave energy dispersion.

The enhanced AUSSM is associated with an upper-level anticyclone over the Australia and excites a zonal wave train along the westerly jet (Fig. 5c). The Australian high generates northward cross-equatorial flows and an upperlevel anticyclone over the Southeast Asia, which seems to enhance a cyclonic anomaly over the northwest Pacific that strengthens East Asian northeast winter monsoon. The subsidence over the equatorial Pacific associated with a strong AUSSM also induces a double anticyclones reside both sides of the equator in the central Pacific. Its teleconnection is strongest among all regional monsoons and has a global scale.

A strong SAFSM features a reinforced upper-level divergent anticyclone over Madagascar which generates strong northward cross-equatorial flow that forms an anticyclone over northern Africa and Arabian Peninsula (Fig. 5d). In the SH, the enhanced SAFSM links to suppressed precipitation in AUSSM region possibly by inducing upper-level convergence there. There is a meridional teleconnection across tropics over the eastern Atlantic sector.

The teleconnection associated with an enhanced WNPSM is oriented primarily in North-south direction (Fig. 5e). In the NH, it resembles the Pacific-Japan Pattern found by Nitta (1987). A notable teleconnection also extends to SH with an enhanced Australian High, suggesting its potential impact on the Australian winter monsoon (Lin 2009).

Of interesting is that a strong SASM is linked to a salient meridional teleconnection pattern across tropics over the Atlantic sector (Fig. 5f). A pronounced anomalous cyclonic anomaly is seen in the midlatitude North AmericaNorth Atlantic during a strong SASM. This indicates a strong linkage between an enhanced North American winter monsoon trough and the summer rainfall anomalies in the SASM.

The enhanced NASM rainfall features southward cross equatorial flows and associated double anticyclone in the upper-level (Fig. 5g). In NH, associated with the northern anticyclone is a tri-pole wave train pattern from the eastern North Pacific via Canada to northern North Atlantic, indicating the impact of the enhanced NASM on Atlantic Ocean. This pattern is similar to the intraseasonal teleconnection pattern found by Moon et al. (2012). In SH, the upper level anticyclone centered at $20^{\circ} \mathrm{S}$ from eastern Pacific to South America also tends to link with downstream low-pressure anomalies.

A prominent common feature of the tropical monsoon teleconnection is the salient cross-equatorial flows as shown in the schematic diagram Fig. 6, which consists of 


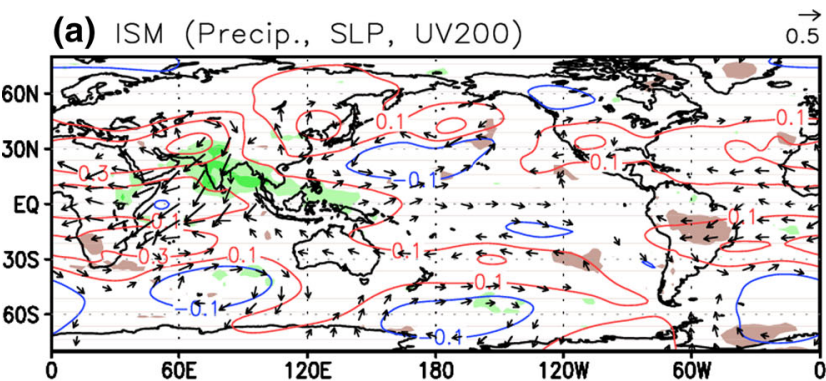

(b) NAFSM

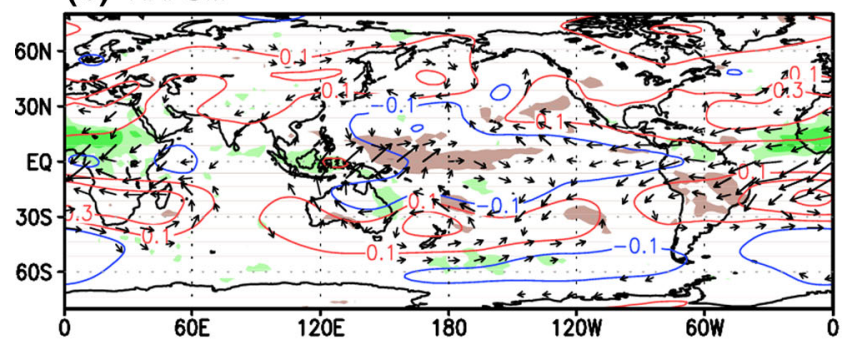

(c) AUSSM

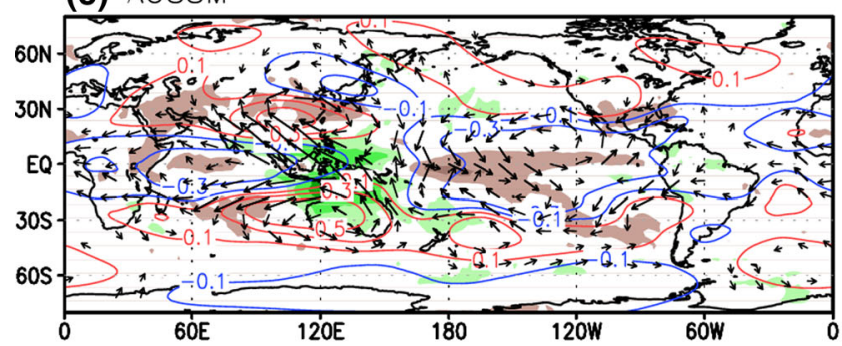

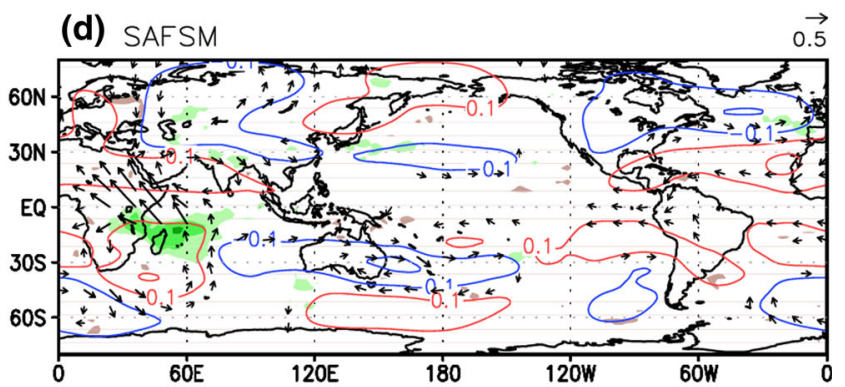

(e) WNPSM

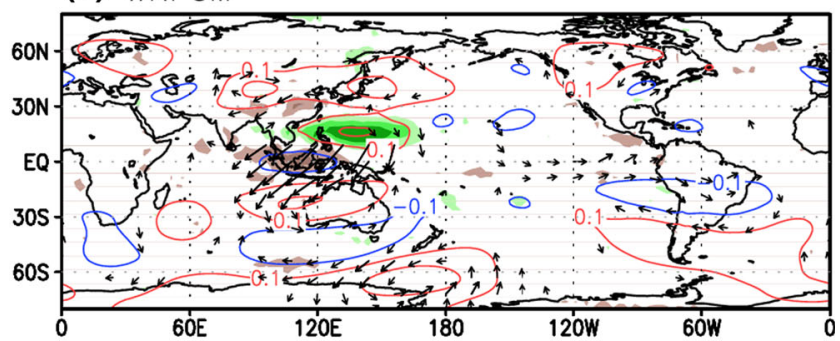

(f) SASM

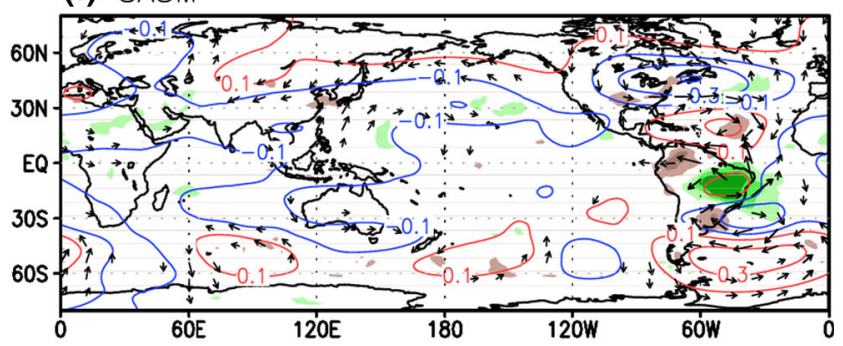

(g) NASM

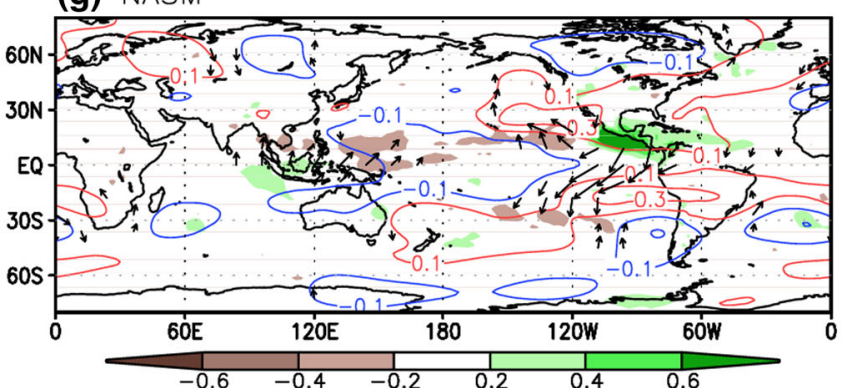

Fig. 5 Same as in Fig. 4 except for precipitation (shading), $200 \mathrm{hPa}$ geopotential height (contour) and $200 \mathrm{hPa}$ winds (vectors)

upper-level flow from the summer to the winter hemisphere and low-level flow from the winter to summer hemisphere. Associated with this local meridional overturning circulation is a pair of upper-level anticyclones that reside in the subtropics of both hemispheres. Note that the summer hemispheric anticyclones have a baroclinic circulation structure; but the winter hemispheric anticyclones have a barotropic structure. This pattern differs from the Gill (1980) solution under a specified anti-symmetric "monsoonal" type heating, which produces upper-level anticyclone in the heating hemisphere and a cyclone in the cooling hemisphere, both have baroclinic structures. The reason is that the monsoonal heating in the summer hemisphere is a driver whereas the upper-level anticyclone in the winter hemisphere is a passive response. That is why the vertical structure of the winter hemisphere response is barotropic. In addition, the Gill theory does not involve mean background flows. The presence of the seasonal mean background flows can modify Gill solution to create secondary features that differ from region to region.

The differences in the regional monsoon teleconnection patterns are also notable. There are two different types of tropical monsoon teleconnection patterns that are connected to the upper-level double anomalous anticyclones. 
(a) NH summer monsoon

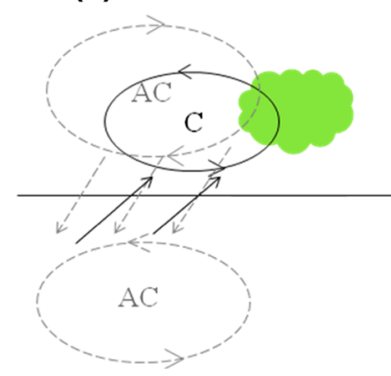

(b) $\mathrm{SH}$ summer monsoon

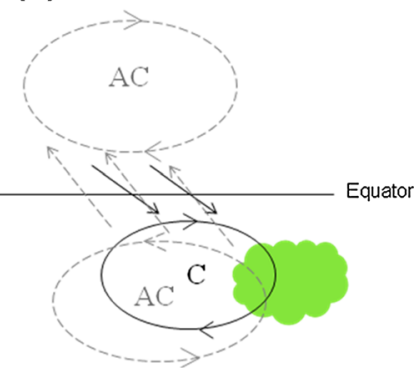

Fig. 6 Schematic diagram showing common features of the anomalous monsoon circulation for the $\mathbf{a} \mathrm{NH}$ and $\mathbf{b} \mathrm{SH}$ regional summer monsoons. The green shading represents the precipitation condensation heating. The black solids and gray dashed lines are at the lowerlevel and upper-level, respectively

The first type, namely zonal type, including ISM, NAFSM, and AUSSM, has significant zonal wave trains emanated from the upper-level double anticyclone downstream along the waveguide associated with the westerly jets in both hemispheres. The second type, i.e. meridional type, including the WNPSM and SASM, has primarily a northsouth oriented teleconnection pattern emanated from the upper-level double anticyclone toward high latitudes in both hemispheres. The SAFSM and NASM seem to have mixed features of both the zonal and meridional teleconnection patterns.

\section{Interdecadal change of monsoon-ENSO relationship}

As is well known, an enhanced ISM is associated with central equatorial cooling and western North Pacific warming (Fig. 7a) signifying concurrence with developing La Niña events. An enhanced NAFSM is associated with a grand triangle cooling in the eastern Pacific and a K-shape warming over the western Pacific (Fig. 7b), a feature similar to Interdecadal Pacific Oscillation (Power et al. 1999) and mega-ENSO (Wang et al. 2013). An enhanced NASM also concurs with equatorial central Pacific cooling (Fig. 7c). Results from Fig. 7a-c suggest that the equatorial central Pacific cooling may strengthen the ISM, NAFSM, and NASM in a coordinated manner during the development of a cold phase of ENSO. The enhanced WNPSM rainfall, however, is associated with dipole SST anomalies over the Indo-Pacific warm pool: warming to the east of the Philippine anticyclonic wind anomaly and cooling to the west of it (Fig. 7d). This dipole SST pattern tend to occur on the decaying phase of an El Nino and has been attributed to the atmosphere-ocean interaction that maintains both the WNPSM and warm pool ocean SST anomalies (Wang et al. 2001; Lau and Nath 2006; Wang et al. 2013; Xiang et al. 2013). As for the SH regional monsoons, an enhanced Australian summer monsoon is obviously associated with a mature state of La Niña (Fig. 7e) as well known from previous studies. An enhanced SASM concurs with a weak eastern tropical Pacific cooling and a pronounced SST dipole in the Southwest Atlantic Ocean (Fig. 7f). The South Atlantic dipole SST is presumably involving local atmosphereocean interaction in the subtropical Atlantic, similar to that of the WNPSM. In Southern Africa, a stronger summer monsoon appears to be associated with basin-wide warming in entire tropics (Fig. 7g). The SAFSM has no significant correlations with ENSO.

The land monsoon rainfall for each of regional monsoons tends to be better correlated with ENSO than the oceanic monsoon rainfall. Therefore, we examine how the regional land monsoon rainfall is related to ENSO during an ENSO-year defined as the year from June 1st of a calendar year to May 31st of the next year (Wang et al. 2013). The results shown in Table 3 indicate that the land monsoon precipitations at all tropical regional monsoons over the past 52 years (CRU data) and the past 34 years (GPCP data) are negatively correlated with the ENSO index. Majority of the negative correlation coefficients are significant at $95 \%$ confidence level. This indicates that ENSO can drive global tropical monsoon rainfall variability. This conclusion is important because it reveals that on interannual time scale the global monsoon concept is useful, although large regional differences exist (Wang et al. 2012a).

In order to detect interdecadal changes of the relationship between each regional summer monsoon and ENSO, we examine the circulation indices from 1958 to 2012 and calculated an 11-year sliding correlation coefficient between Niño3.4 SST anomaly and each regional summer monsoon vorticity circulation index. The results in Fig. 8a show that the negative ISM circulation index-ENSO relationship has experienced a marked weakening since the late 1970s, similar to the All Indian summer rainfall (Kumar et al. 1999); but a significant negative relationship has become recovered after 2000s. The later change in the turn of the century is noteworthy. The WNPSM has a significant negative correlation with the previous winter ENSO index and this correlation has been strengthened since the late 1970s (Fig. 8b). The SASM-ENSO relationship also tends to be strengthened since the late 1970s (Fig. 8c). The late 1970s appears to be a common changing point for ISM, WNPSM and SASM in their relationships with ENSO. This may be due to the change of ENSO properties in the late 1970s, i.e., the increased amplitude of ENSO (Wang et al. 2008b). The NASM and NAFSM have similar relationships with ENSO after the early-mid 1970s; both show significant negative correlations with ENSO (Fig. 8d, e). The SAFSM-ENSO relationship is insignificant for the entire 1958-2012 period (Fig. 8f). Most steady negative 
(a) ISM (JJAS SST)

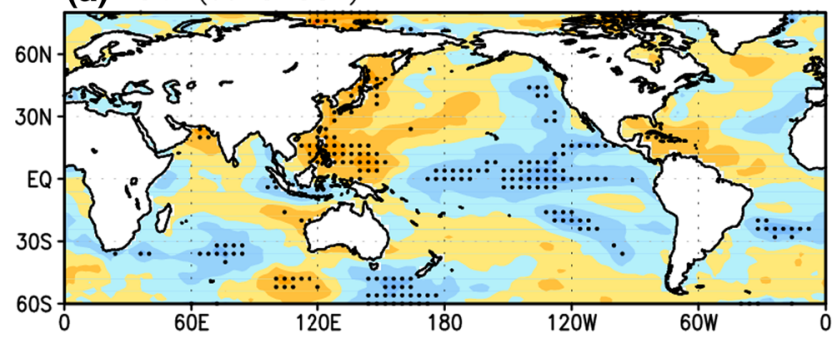

(b) NAFSM (JJAS SST)

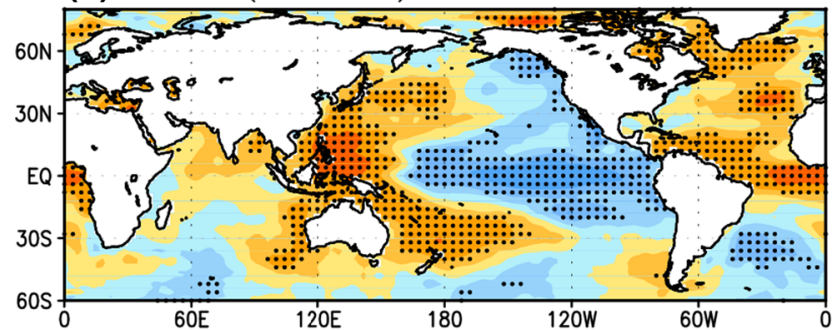

(c) NASM (JJAS SST)

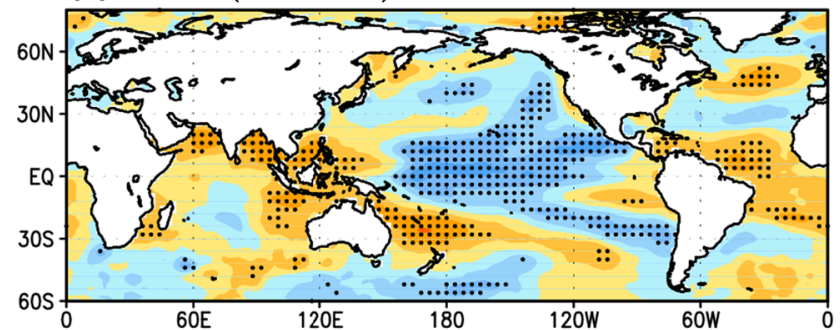

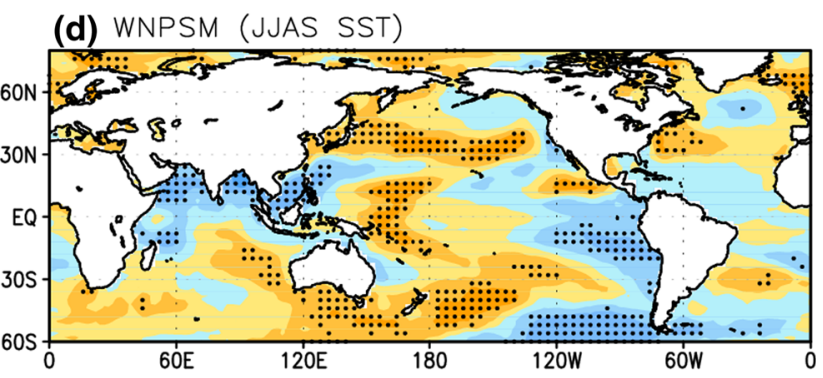

(e) AUSSM (DJFM SST)

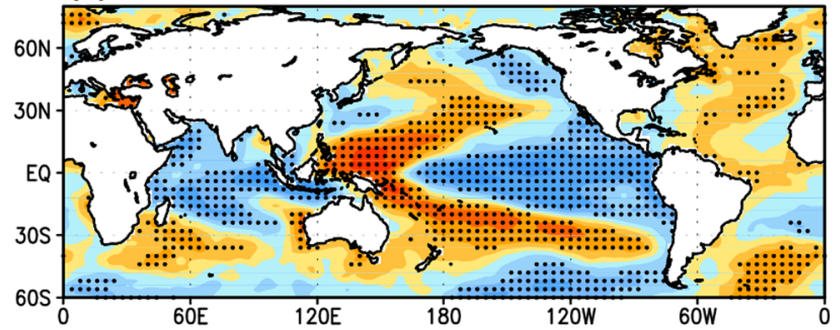

(f) SASM (DJFM SST)

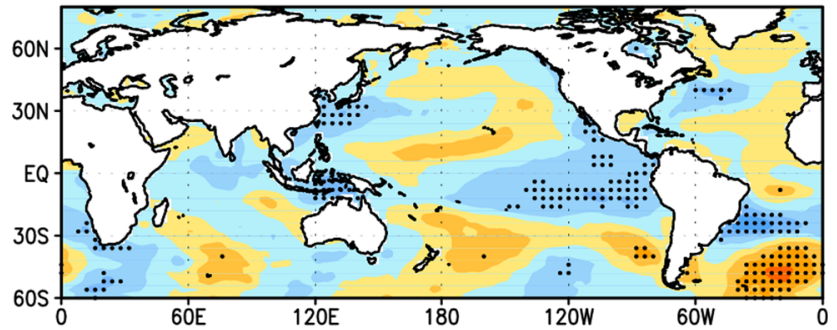

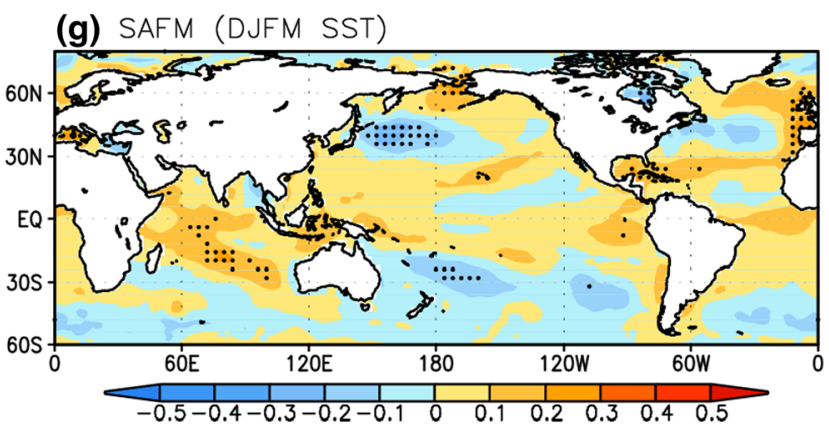

Fig. 7 Simultaneous correlation coefficient map of SST anomalies with respect to the time series of each regional summer monsoon precipitation index. The areas with correlation coefficients significant above $95 \%$ confidence level are dotted

correlation is found only for the AUSSM (Fig. 8g). This indicates that the AUSSM may be most predictable among all regional monsoons.

In sum, over the past 55 years, all the regional monsoon-ENSO relationships are unsteady except that between AUSSM and ENSO which shows a steady and strong negative correlation. The common decadal changing points in the regional monsoon-ENSO relationship are found in 1970s. The relationships was enhanced for WNPSM, NASM, NAFSM, and SASM, but weakened for the ISM.
The recent strengthening of the Indian monsoon-ENSO relationship in late 1990s is a noteworthy feature.

\section{Conclusion and discussion}

Our study examined meteorological basis for construction of regional monsoon indices and explored the common features and regional differences of the teleconnection and monsoon-ENSO relationship among tropical regional 
Table 3 The correlation coefficients of ENSO-year mean time series between the Niño3.4 SST index and the precipitations over land areas of the seven tropical regional monsoons

\begin{tabular}{lll}
\hline $\begin{array}{l}\text { Land monsoon } \\
\text { precipitation }\end{array}$ & $\begin{array}{l}\text { CC } \\
\text { GPCP } \\
(1979-2012)\end{array}$ & $\begin{array}{l}\text { CC } \\
\text { CRU } \\
(1958-2009)\end{array}$ \\
\hline IN & $-0.60^{*}$ & $-0.58^{*}$ \\
WNP & $-0.61^{*}$ & $-0.57^{*}$ \\
NAM & $-0.72^{*}$ & $-0.43^{*}$ \\
NAF & $-0.36^{*}$ & -0.24 \\
SAM & -0.25 & -0.15 \\
SAF & $-0.48^{*}$ & $-0.51^{*}$ \\
AUS & $-0.73^{*}$ & $-0.72^{*}$ \\
\hline
\end{tabular}

The precipitation data used are GPCP V2 and CRU over land monsoon areas only. The values with a "*" symbol denote statistical significant at $95 \%$ confidence level monsoons. The results related to these two aspects are summarized and discussed as follows:

\subsection{Conclusion}

What is the physical basis for constructing regional monsoon indices? We have shown that area-averaged summer rainfall intensity provides a meaningful measure of precipitation index for tropical monsoons because it represents well (a) the amplitude of annual cycle (monsoon strength), (b) the principal components of the summer-to-summer rainfall variability, and (c) the corresponding spatial pattern is nearly uniform (Table 1; Fig. 3). The tropical regional monsoon circulation indices were defined in a unified approach measuring monsoon trough vorticity for seven tropical monsoon regions. The defined monsoon
Fig. 8 Sliding correlation coefficients between each regional summer monsoon vorticity circulation index and ENSO with a window of 11-year for the period 1958-2012. The red horizontal line indicates the $95 \%$ confidence level (a) (ISM, JJA Nino3.4)

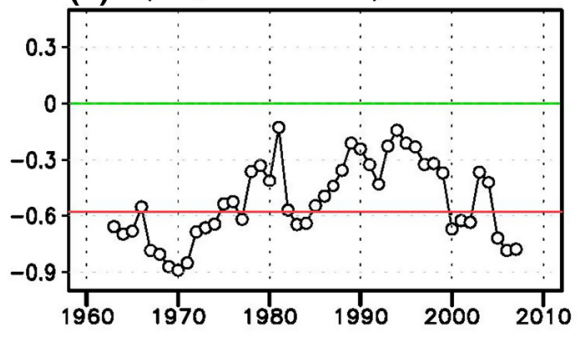

(b) (WNPSM, DJF(-1) Nino3.4)

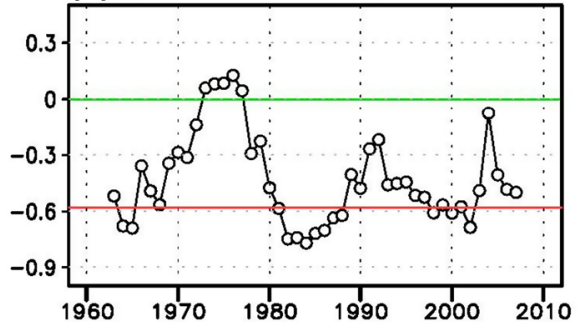

(c) (SASM, DJF Nino3.4)

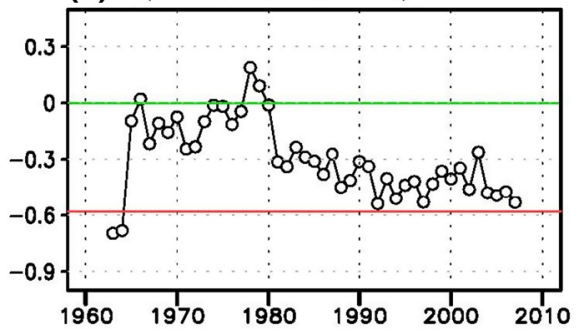

(d) (NASM, JJA Nino3.4)

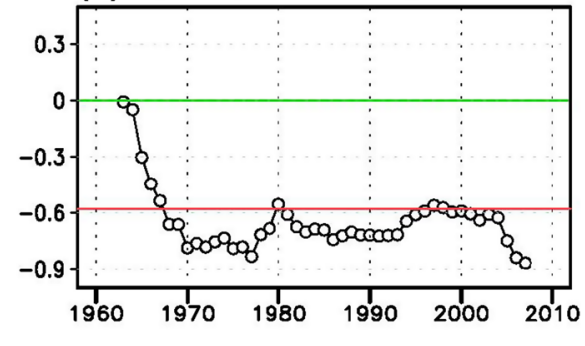

(e) (NAFSM, JJA Nino3.4)

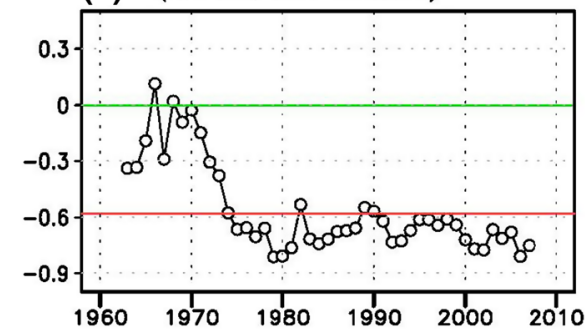

(f) (SAFSM, DJF Nino3.4)

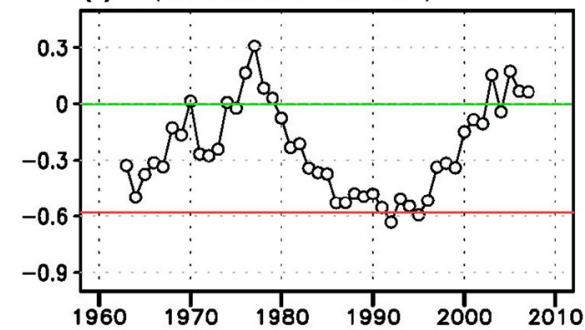

(g) (AUSSM, DJF Nino3.4)

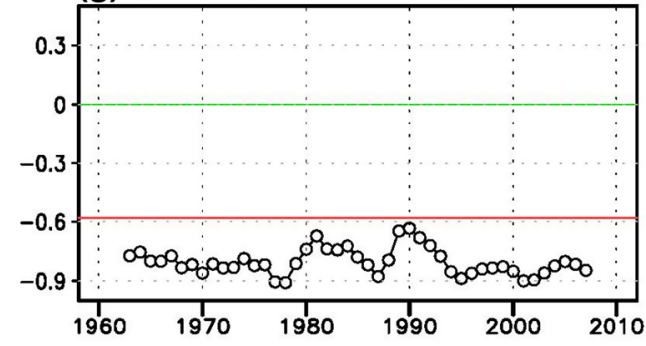


circulation indices are highly correlated with corresponding monsoon precipitation indices on sub-seasonal and interannual time scales (Table 2).

By comparison of the teleconnection patterns associated with an enhanced regional monsoon, we found the commonality and differences among seven tropical monsoons. The teleconnection is commonly characterized by upperlevel double anticyclones residing in the subtropics of both hemispheres which are connected by salient cross-equatorial flows and a local meridional overturning circulation (Figs. 5, 7), indicating a strong linkage between summer monsoons in one hemisphere and winter monsoons in the other hemisphere. Note that the summer hemispheric anticyclone is a result of the heating due to enhanced monsoon rainfall whereas the winter hemispheric anticyclone is a passive response which generates subsidence and dry climate. In addition to the double anticyclone, the teleconnection patterns associated with the seven tropical summer monsoons can be recognized as two types. The zonal type, including the ISM, NAFSM and AUSSM, exhibits significant zonal wave trains emanated from the upper-level double anticyclones downstream the westerly jet. The meridional type, including the WNPSM and SASM, displays dominant meridional wave trains emanated from the double anticyclones polewards in both hemispheres. The SAFSM and NASM seem to have mixed features of both the zonal and meridional teleconnection patterns. This difference between the two types of monsoon teleconnection may be related to the differences in the seasonal mean flows but numerical experiments are needed to test this hypothesis.

In the regional monsoon-ENSO relationship, we found that over the past 55 years (1958-2012) nearly all regional monsoons have non-stationary relationship with ENSO except the AUSSM which has the strongest and stable negative correlation with ENSO index. Two decadal changing points are found in 1970s. Since early 1970s, the monsoon-ENSO relationship has been strengthened in Northern Africa and North America. Since the late 1970s, the monsoon-ENSO relationship has strengthened in western North Pacific and South America but weakened over India. The weakening of ISM-ENSO relationship is a local phenomenon, which is opposite to changes in the WNP, North Africa, and South and North America. It is of interest that the ISM-ENSO relationship seems to be recovered toward the end of the twentieth century.

Regardless the large regional difference, the monsoon precipitations over land areas of all tropical regional monsoons are significantly correlated with the ENSO during an ENSO year (from June to the next May) (Table 3), suggesting that on interannual time scale, ENSO drives global scale tropical monsoon rainfall variability. On the other hand, the reason for the large scale interdecadal change of monsoon-ENSO relationship in 1970s calls for further study. The interdecadal changes in the ENSO properties and associated planetary circulation might be one of the reasons (Kumar et al. 1999; Wang et al. 2008b; Lee et al. 2013). Other factors may also be involved (e.g., C. P. Chang et al. 2001; Wu et al. 2012a, b), but this remains an issue for future investigations.

\subsection{Discussion}

Among eight regional monsoons, EASM is a subtropical monsoon which differs from the other seven tropical regional monsoons. Therefore, EASM has special features that are not in common to other regional monsoons. First, use of an area-averaged precipitation index over East Asia is not quite proper because the leading mode of precipitation variation is not dominated by a uniform pattern (Fig. 3c). The corresponding circulation index is also less correlated to the precipitation. This explains in part why the definition of the EASM index has been controversial. A detailed discussion of EASM indices is referred to Wang et al. (2008a).

For the convenience of comparison with proxy data, local wind anomalies may be more desirable than the vorticity indices. The regional monsoon westerly indices defined by using $850 \mathrm{hPa}$ zonal wind speed for seven tropical regional monsoons are well correlated with the corresponding regional monsoon precipitation indices (not shown) but the vorticity indices are generally better than westerly indices. Therefore, our circulation indices are useful for both the modern and paleo-monsoon study.

The proposed tropical regional monsoon precipitation and circulation indices are helpful for monitoring regional monsoon changes from summer-to-summer at each region. These indices can also be monitored on pentad mean basis which would reflect intraseasonal variability of the regional monsoons. This has been partly demonstrated in previous studies (e.g., Wang et al. 2009; Kajikawa et al. 2009). These indices also provide useful metrics for assessment of the climate model's performances in simulating the global monsoon and facilitate detect of the future changes of the regional monsoons.

Acknowledgments This work was jointly supported by the National Research Projects of China (Award Nos. XDA05080800, 2010CB950102), NOAA/MAPP program, the National Research Foundation (NRF) of Korea through a Global Research Laboratory (GRL) grant of the Korean Ministry of Education, Science and Technology (MEST, \#2011-0021927), and the National Basic Research Program of China (Award No. 2013CB430202). We acknowledge support from the International Pacific Research Center (IPRC), which is in part supported by Japan Agency for Marine-Earth Science and Technology (JAMSTEC), National Oceanic and Atmospheric Administration (NOAA), and National Aeronautics and Space 
Administration (NASA). Discussion with Prof. Pinxian Wang at Tongji University has enriched motivation of this study. The authors are also acknowledging anonymous reviewers' comments on an early version of the manuscript. This is publication No 9011 of the School of Ocean and Earth Science and Technology (SOEST) and publication No 1016 of the IPRC.

Open Access This article is distributed under the terms of the Creative Commons Attribution License which permits any use, distribution, and reproduction in any medium, provided the original author(s) and the source are credited.

\section{References}

Chang CP, Patrick H, Jianhua J (2001) Possible roles of Atlantic circulations on the weakening Indian monsoon rainfall-ENSO relationship. J Clim 14:2376-2380

Dee DP et al (2011) The ERA-Interim reanalysis: configuration and performance of the data assimilation system. Q J R Meteorol Soc 137:553-597

Ding QH, Wang B (2005) Circumglobal teleconnection in the Northern Hemisphere summer. J Clim 18:3483-3505

Ding QH, Wang B, Wallace M (2011) Tropical-extratropical teleconnections in boreal summer: observed interannual variability. J Clim 24:1878-1896

Gill AE (1980) Some simple solutions for heat-induced tropical motion. Q J R Meteorol Soc 106:447-462

Goswami BN, Krishnamurthy V, Annamalai H (1999) A broadscale circulation index for interannual variability of the Indian summer monsoon. Q J R Meteorol Soc 125:611-633

Higgins RW, Douglas A, Hanmann A et al (2003) Progress in Pan American CLIVAR research: the North American Monsoon System. Atmosfera 16:29-65

Huffman GJ, Bolvin DT, Adler RF (2011) Last updated GPCP version 2.2 combined precipitation data set. WDC-A, NCDC, Asheville, NC (2011). Dataset accessed at http://www.ncdc. noaa.gov/oa/wmo/wdcamet-ncdc.html

Kajikawa Y, Wang B, Yang J (2009) A multi-time scale Australian monsoon index. Int J Climatol 30:1114-1120

Kumar KK, Rajagopalan B, Cane MA (1999) On the weakening relationship between the Indian monsoon and ENSO. Science 284:2156-2159

Lau NC, Nath MJ (2006) ENSO modulation of the interannual and intraseasonal variability of the East Asian monsoon: a model study. J Clim 19:4508-4530

Lee EJ, Ha KJ, Jhun JG (2013) Interdecadal changes in interannual variability of the global monsoon precipitation and interrelationship among its subcomponents. Clim Dyn. doi: 10.1007/ s00382-013-1762-4

Lin H (2009) Global extratropical response to diabetic heating variability of the Asian summer monsoon. J Atmos Sci 66:2697-2713

Liu Z, Harrison SP, Kutzbach JE, Otto-Bliesner B (2004) Global monsoons in the mid-Holocene and oceanic feedback. Clim Dyn $22: 157-182$

Liu J, Wang B, Ding QH, Kuang XY, Soon W, Zorita E (2009) Centennial variations of the global monsoon precipitation in the last millennium: results from ECHO-G model. J Clim 22:2356-2371

McBride JL (1987) The Australian summer monsoon. In: Chang C-P, Krishnamurty TN (eds) Monsoon meteorology. Oxford Unversity Press, Oxford, pp 203-231
Mitchell TD, Jones PD (2005) An improved method of constructing a database of monthly climate observations and associated highresolution grids. Int J Climatol 25:693-712

Moon JY, Wang B, Ha KJ, Lee JY (2012) Teleconnections associated with Northern Hemisphere summer monsoon intraseasonal oscillation. Clim Dyn. doi:10.1007/s00382-012-1394-0

Nicholson SE, Kim E (1997) The relationship of the El Nino Southern oscillation to African rainfall. Int J Climatol 17:117-135

Nitta T (1987) Convective activities in the tropical western Pacific and their impact on the Northern Hemisphere summer circulation. J Meteor Soc Jpn 65:373-390

Parthasarathy B, Kumar R, Kothawale DR (1992) Indian summer monsoon rainfall indices, 1871-1990. Meteor Mag 121:174-186

Power S, Casey T, Folland CK, Colman A, Mehta V (1999) Interdecadal modulation of the impact of ENSO on Australia. Clim Dyn 15:319-323

Smith TM, Reynolds RW, Peterson TC, Lawrimore J (2008) Improvements to NOAA's historical merged land-ocean surface temperature analysis (1880-2006). J Clim 21:2283-2296

Tao S, Chen L (1987) A review of recent research on the East Asian summer monsoon in China. In: Chang C-P, Krishnamurti TN (eds) Monsoon meteorology. Oxford University Press, Oxford, pp 60-92

Uppala SM, Kallberg PW, Simmons AJ, Andrae U, Da Costa Bechtold V, Fiorino M, Gibson JK, Haseler J, Hernandez A, Kelly GA, Li X (2005) The ERA-40 reanalysis. Q J R Meteorol Soc 131:2961-3012

Wang B, Fan Z (1999) Choice of South Asian summer monsoon indices. Bull Am Meteor Sci 80:629-638

Wang B, Wu R, Lau KM (2001) Interannual variability of Asian summer monsoon: contrast between the Indian and western North Pacific-East Asian monsoons. J Clim 14:4073-4090

Wang B, Wu Z, Li J, Liu J, Chang CP, Ding Y, Wu G (2008a) How to measure the strength of the East Asian summer monsoon. J Clim 17:4449-4462

Wang B, Yang J, Zhou T, Wang B (2008b) Interdecadal changes in the major modes of Asian-Australian monsoon variability: strengthening relationship with ENSO since the late 1970s. J Clim 21:1771-1789

Wang B, Huang F, Wu Z, Yang J, Fu X, Kikuchi K (2009) Multiscale climate variability of the South China sea monsoon: a review. Dyn Atmos Ocean 47:15-37

Wang B, Liu J, Kim HJ, Webster PJ, Yim SY (2012a) Recent change of the global monsoon precipitation (1979-2008). Clim Dyn 39:1123-1135

Wang H, Wang B, Huang F, Ding Q, Lee JY (2012b) Interdecadal change of the boreal summer circumglobal teleconnection (1958-2010). Geophys Res Lett 39:L12704. doi:10.1029/ 2012GL052371

Wang B, Liu J, Kim HJ, Webster PJ, Yim SY, Baoqiang Xiang (2013) Northern hemisphere summer monsoon intensified by mega-El Nino/southern oscillation and Atlantic multidecadal oscillation. PNAS 110:5347-5352

Webster PJ, Yang S (1992) Monsoon and ENSO: selectively interactive systems. Q J R Meteor Soc 118:877-926

Webster PJ, Magana VO, Palmer TN, Shukla J, Tomas RA, Yanai M, Yasunari T (1998) Monsoons: processes, predictability, and the prospects for prediction. J Geophys Res 103:14451-14510

Wu Z, Li J, Jiang Z, He J, Zhu X (2012a) Possible effects of the North Atlantic Oscillation on the strengthening relationship between the East Asian summer monsoon and ENSO. Int J Climatol 32:794-800

Wu Z, Li J, Jiang Z, Ma T (2012b) Modulation of the Tibetan Plateau snow cover on the ENSO teleconnections: from the East Asian summer monsoon perspective. J Clim 25:2481-2489 
Xiang B, Wang B, Yu W, Xu S (2013) How can western North Pacific subtropical high intensify from early to late summer? Geophys Res Lett. doi:10.1002/grl.50431

Xie P, Arkin PA (1997) Global precipitation: a 17-year monthly analysis based on gauge observations, satellite estimates, and numerical model outputs. Bull Am Meteorol Soc 78: 2539-2558

Zhou JY, Lau KM (1998) Does a monsoon climate exist over South America? J Clim 11:1020-1040 